Людмила Кримець, доктор філософських наук, старший науковий співробітник Національний університет оборони України імені Івана Черняховського ORCID ID 0000-0001-7451-5208

Руслан Калениченко, кандидат психологічних наук, доцент DOI 10.33099/2617-1775/2019-01/150-160

\title{
ЕТИЧНІ КОДЕКСИ ПОВЕДІНКИ В КОНТЕКСТІ ФОРМУВАННЯ МЕНТАЛЬНОСТІ ВІЙСЬКОВОСЛУЖБОВЦІВ ТА ПРОТИДІЇ ГЕНДЕРНІЙ ДИСКРИМІНАЦІЇ
}

Автором визначено аксіологічний аспект сучасних військових етичних кодексів поведінки у контексті формування ментальності військовослужбовців сектору безпеки $i$ оборони України на засадах демократичних принципів та морально-етичних стандартів, прийнятих у країнах-членах НАТО. В статті проаналізовано фундаментальні принципи та етичні категорії Кодексу честі офіцера Збройних Сил Украӥни, Кодексу поведінки військового та ицвільного персоналу НАTO “The NATO Code of Conduct” та принципи, закладені у проекті уніфікованого Статуту військовослужбовців сектору безпеки та оборони України з акцентом на концептуалізацію принщипу тендерної рівності та протидї гендерній дискримінації.

Ключові слова: військова етика; військова освіта; етичний кодекс; кодекс честі військовослужбовия; тендерна рівність; тендерна дискримінащія; ментальність військовослужбовия; демократичні иүінності.

Актуальність дослідження. Етичні Кодекси, Кодекси честі військовослужбовців у секторі безпеки та оборони України - це важливий засіб формування ментальності, виховання, згуртування офіцерського корпусу, розвитку у військовослужбовців високої морально-психологічної готовності до виконання завдань щодо забезпечення оборони України.

Стратегічним оборонним бюлетенем України, введеним в дію Указом Президента України від 6 червня 2016 року № 240/2016, передбачається, що професіоналізація сил оборони та створення необхідного військового резерву в Україні повинні впроваджуватись на засадах і принципах, якими керуються держави - члени НАТО. При цьому розвиток соціально-гуманітарного забезпечення персоналу сил оборони, у першу чергу військовослужбовців, пов’ язується зі змінами в ментальності (образі мислення) особового складу, яка, у свою чергу, повинна базуватися на основі європейських цінностей.

Метою статті $\epsilon$ визначення аксіологічного змісту сучасних військових етичних кодексів поведінки у контексті формування ментальності військовослужбовців сектору безпеки i оборони України на засадах демократичних принципів та морально-етичних стандартів, прийнятих у країнах-членах НАТО з акцентом на концептуалізацію принципу гендерної рівності.

Виклад основного матеріалу. Згідно авторської концепції, ментальність військовослужбовця являє собою систему, що динамічно розвивається, в якій відбувається зрощування не тільки особистісного, а й професійного розвитку. 
Ментальність військовослужбовців Збройних Сил України та інших складових сил оборони, визначається як інтегративна професійно-обумовлена соціокультурна властивість, що зумовлює специфіку їх світосприйняття, образ мислення, особливості формування колективної та індивідуальної свідомості та професійної поведінки $[2,3,4,5]$.

Ментальність особистості багато в чому залежить від домінуючих в суспільстві цінностей, що визначають мотиви іiі життєдіяльності, значимість яких важко переоцінити. Ціннісна трансформація ментальності передбачає перш за все зміну ціннісних орієнтацій особистості. Сучасне суспільство надає широкі можливості для задоволення потреб, домагань та інтересів кожної людин. Тим часом, засоби досягнення мети регламентовані усталеними в суспільстві нормами поведінки, традиціями та цінностями.

Традиції офіцерського корпусу сучасного українського війська втілює Кодекс честі офіцера Збройних Сил України, що введений у дію Наказом Міністра оборони України № 412 від 31.12.1999 р. Як нормативний документ морального регулювання взаємовідносин в офіцерській спільноті, він базується і на вимогах Конституції України, Військової присяги, статутів Збройних Сил України, і на стандартах гуманітарного права. Тому за своїм змістом він $\epsilon$ оптимальним поєднанням морального і правового у військовій діяльності й спрямований на захист честі та гідності кожного офіцера, підвищення єдності офіцерського корпусу, піднесення його авторитету.

Кодекс честі офіцера Збройних Сил України - це сукупність моральноетичних норм, які визначають ціннісну орієнтацію світогляду офіцера i принципово регламентують його стосунки з соціальним оточенням, службову та громадську діяльність. На відміну від Статутів Збройних Сил України, в основі Кодексу лежить принцип рівності всіх офіцерів, незалежно від звання і посади, ґендерних характеристик, перед військовою честю.

Головну його ідею можна сформулювати кількома словами: офіцер Збройних Сил України повинен бути прикладом чесного й сумлінного виконання своїх службових обов'язків, служіння Батьківщині, дотримуватись принципу поваги до честі і гідності всіх військовослужбовців без винятку. Принциповим $\epsilon$ те, що Кодекс визначає саме норми поведінки, а не відповідальність за їх порушення і не $\epsilon$ механізмом розв'язання конкретних ситуацій. Разом $з$ тим, важливими його функціями є: орієнтація офіцера на певний спосіб життя, стиль поведінки; впровадження в життя загальнолюдських, військових цінностей та формування на їх основі людини XXI століття як патріота, професіонала; утвердження поваги, довіри, відповідальності у взаєминах офіцерів [1].

Значення ролі Кодексу можна розкрити через розгляд його функцій. Перерахуємо основні функції Кодексу честі офіцера ЗС України.

Регулятивна функиія. Кодекс є морально-етичним регулятором поведінки військовослужбовця. Моральні норми і приписи, які містить у собі Кодекс честі, орієнтують офіцера на певний образ життя, стиль діяльності, лінію поведінки, і тим самим значною мірою регулюють його життєдіяльність, 
взаємовідносини з начальниками та підлеглими, старшими і молодшими. Це регулювання без примусу, базується на основі переконань, через засвоєння, повне сприйняття моральних вимог, які перетворюються на чітку внутрішню позицію офіцера.

Комунікативна функція. Кодекс сприяє формуванню позитивного комунікативного середовища в межах офіцерського корпусу. Якщо офіцери засвоюють, і підтримують вимоги Кодексу честі, то між ними складаються певні комунікативні зв' язки, сформовані на основі взаємоповаги, взаємодовіри, принципу рівності та недискримінації.

Виховна функція. Кодекс виховує військовослужбовця в контексті поваги до найкращих військових традицій та базових цінностей. Засвоєння положень Кодексу честі $є$ процесом пізнання морально-етичних норм та правил поведінки, що у свою чергу виступає важливою передумовою виховання у офіцерів необхідних моральних якостей.

Кодекс честі офіцера грунтується на таких фундаментальних цінностях як: гуманізм, людяність, рівність, повага до особистості і піклування про неї, любов до Батьківщини, самовіддане служіння ій, українському народові, вірність Військовій присязі; чесність і порядність. Кодекс честі офіцера Збройних Сил України тісно переплітається 3 військовим етикетом, основою якого є вимоги моралі, проведені крізь призму військової служби, Військову присягу, військові Статути, накази, постанови, директиви.

Окремо, слід зазначити, що до впровадження в практику підготовки офіцерів поліції відповідних “етичних кодексів поліцейських" в більшості країн Європи ставляться досить серйозно. Так, “Кодекс деонтології національної поліції Франціі” став одним 3 перших повноцінних документів 3 етики поліцейських. В Німеччині деонтологію викладають в навчальних закладах, де готують майбутніх поліцейських.

Основним міжнародним документом, що визначає базові демократичні цінності сучасного війська, вимоги до етико-моральних характеристик особового складу армій більшості країн світу є "The NATO Code of Conduct". У кодексі "The NATO Code of Conduct" зазначено, що Організація Північноатлантичного альянсу (НАТО) передбачає сприяння найвищому рівню довіри між його членами та вимагає від них єдності, вірності, відповідальності, неупередженості і професіоналізму незалежно від гендерних ознак. Ці п'ять основних цінностей складають аксіологічну основу етичного Кодексу, який визначає вимоги до поведінки всіх цивільних та військових співробітників та персоналу підрозділів НАТО [9].

\section{Єдність, Вірність, Відповідальність, Неупередженість та} Професіоналізм - $\epsilon$ фундаментальними демократичними цінностями, що мають складати основу ментальності сучасних військовослужбовців сектору безпеки та оборони України, бути відображені в військових статутах, тексті Військової присяги, з врахуванням національних особливостей та передового світового досвіду формування ментальності військовослужбовців. 
Відповідно до “The NATO Code of Conduct" ЄДНІСТЬ має реалізовуватися як:

- чесність та правдивість у професійних відносинах;

- уникання ситуацій, які можуть призвести до виникнення міжособистісних конфліктів, потенційних конфліктів між особистими та національними інтересами;

• виконання негайних дій, щодо недопущення виникнення та врегулювання конфліктних ситуацій у військово-професійному середовищі;

- заборона на використання професійної інформації, отриманої через офіційні джерела, для особистої вигоди;

- поміркованість, уникання дій, які можуть сприйматися як зловживання статусом військовослужбовця (учасника бойових дій) та привілеями, наданими країною.

Відповідно до "The NATO Code of Conduct" ВIPHICTЬ має бути спрямована на:

- підтримку демократичних принципів, на яких був заснований Альянс;

- демонстрацію професійної відданості на шляху до досягнення мети, орієнтованої на реалізацію цілей та завдань військової організації;

- прагнення зробити особистий внесок в успіх військової організації та НАТО, сприяння культурі результатів через Альянс;

- вимогу завжди ставити інтереси альянсу вище власних інтересів та інтересів окремих країн, пам'ятаючи про рівність усіх перед законом;

- формування, сприяння та підтримку позитивного командного духу.

Відповідно до "The NATO Code of Conduct" ВІДПОВІДАЛЬНІСТЬ передбачає:

- відповідальність за власні дії, рішення, або бездіяльність і прийняття їх наслідків та результатів;

- оперативні дії для вирішення або виправлення будь-яких помилок або упущень, які члени альянсу зробили чи можуть зробити;

- прозорість професійної діяльності, навіть за умови ії негативної оцінки;

- усвідомлення наслідків власних дій і рішень, до моменту їх прийняття;

- пильність щодо будь-яких шахрайств та зловживань, які можуть статися в організації та відповідна протидія ним належним чином;

- уникання будь-яких дій, які можуть призвести до пошкодження або ризику для військової організації, іï комунікаційних та інформаційних систем або невідповідне використання і розголошення інформації.

Згідно "The NATO Code of Conduct" НЕУПЕРЕДЖЕНІСТЬ як базова цінність проявляється через наступні вимоги:

- дотримуватись принципів об'єктивності та незалежності у професійних операціях, прагнути бути чесними та справедливими у всіх аспектах діяльності;

- дотримуватись принципу об'єктивності, спиратись на міжнародний досвід та використовувати рекомендації та рішення Альянсу в цілому, не зважаючи на погляди чи інтереси власної, або будь-якої конкретної країни або нації; 
- не приймати подарунки, не допускати проявів гендерної дискримінації, що може поставити під загрозу вашу неупередженість або породити сприйняття браку об'єктивності у вашій поведінці та виконанні службових обов'язків;

- не займатися неавторизованою зовнішньою роботою чи іншими видами діяльності, що може суперечити чи заважати виконанню ваших службових обов'язків;

- не використовувати привілейовану професійну інформацію про діяльність військової організації не за призначенням та 3 метою отримати користь після завершення військової служби.

ПРОФЕСІОНАЛІЗМ як цінність військово-професійної діяльності у змістї "The NATO Code of Conduct" декларується крізь призму вимог до цивільного та військового професіонала:

- докладати максимальних зусиль до повсякденного виконання професійних обов'язків;

• підтримувати найвищий рівень компетенції у власній професійній сфері і прагнути до постійного вдосконалення професійних знань, навичок та вмінь;

- доглядати і обережно використовувати обмежені ресурси військової організації;

- забезпечити безпеку та конфіденційність службової інформації;

- враховувати наслідки власної професійної діяльності щодо природного середовища;

- поважати конфіденційність приватної сфери, гендерну ідентичність та соціальну різноманітність усіх співробітників;

- не переслідувати та не дискримінувати інших співробітників у професійному середовищі, вимагати того ж від інших;

- для керівників та начальників, забезпечити справедливе керівництво та нести відповідальність за дії чи бездіяльність підлеглих, забезпечити сприяння ïx професійному розвитку, заохочуючи і нагороджуючи тих, хто працював добре, виправляючи та навчаючи тих, хто не відповідає стандартам [9].

Влада - у сучасному розвинутому правовому суспільстві $є$ синонімом слова “відповідальність". За умови, коли суспільство формується на базі фундаментальних ліберально-демократичних цінностей, що спрямовані на захист прав людини, впровадження соціокультурної інтерактивності, забезпечення законності і відкритості системи та процесу управління, демократичного цивільного контролю над воєнною організацією та правоохоронними органами держави, принципів гендерної рівності - владою можуть бути наділені лише особи, що володіють відповідними професійними компетенціями та здатністю брати на себе величезний тягар відповідальності [4].

На виконання Державної програми реформування та розвитку Збройних Сил України на період до 2020 року у Збройних силах ведеться робота щодо розробки нового уніфікованого Статуту для військовослужбовців сектору безпеки та оборони України за стандартами НАТО. Відповідно до проекту Статуту: Керівництво військовими формуваннями базується на принципах 
сдиноначальності, доброчесності, індивідуальної відповідальності, лідерства та гендерної рівності, що передбачає відбір, призначення на посади та просування по службі осіб, які мають освіту, досвід і досягнення у певній сфері діяльності та забезпечує постійний розвиток потенціалу військової частини [6].

Принцип лідерства означає сприяння професіоналізації військового формування, створення відповідного військового резерву з урахуванням знань, бойового досвіду, вмінь та здобутків військовослужбовців при призначенні на керівні посади.

Концепт "Лідерство" є базовим для розуміння та сприяння професіоналізації Збройних Сил України та основою професійної підготовки військових та цивільних фахівців в арміях країн - членів НАТО. Відповідно до Польового Статуту щодо розвитку лідерства у Збройних Силах США (Field Manual № 6-22. Leader Development. Headquaters. Departement of the Army. Washington DC, June 2015), Лідерство - це процес впливу на людей через визначення цілі, напрямку іiі досягнення та мотивацію 3 метою виконання поставленого завдання та покращення організації [10].

Військовий лідер, в силу взятої на себе відповідальності, надихає та впливає на людей, домагається досягнення поставлених цілей. Лідери мотивують людей як всередині, так і за межами військового товариства; вони спрямовують власну діяльність, мислення та приймають рішення для забезпечення якомога більш якісних результатів професійної діяльності та розвитку військової організації.

Розвиток лідера - це узгоджений, тривалий та цілеспрямований процес, що базується на військових цінностях та має на меті перетворити військовослужбовців та працівників 3С на компетентних впевнених лідерів, здатних на рішучі дії. Розвиток лідера досягається через постійний синтез практичної підготовки, освіти і досвіду, здобутих у процесі професійної підготовки та навчання в освітніх установах (Institutional Domain), під час участі в операціях (Operational Domain) та процесі саморозвитку (Selfdevelopment Domain) [7, 10].

Принцип єдиноначальності у керівництві військовими формуваннями полягає в наділенні командира (начальника) всією повнотою розпорядчої влади стосовно підлеглих і покладенні на нього персональної відповідальності перед державою за всі сторони життя та діяльності військової частини, підрозділу i кожного військовослужбовця;

Принцип доброчесності вимагає непорушно додержуватися Конституції України та законів України, Військової присяги, сумлінно і доброчесно виконувати військовий обов'язок; запобігати корупції у всіх ii проявах, постійно підвищувати рівень професійних знань, вдосконалювати свої навички і майстерність.

Принцип індивідуальної відповідальності полягає в особистій та нероздільній відповідальності кожного військовослужбовця, незалежно від його посади та військового звання, за виконання покладених на нього 
обов'язків військової служби, дотримання військової дисципліни, вимог Статуту, нормативних та керівних документів, положень, інструкцій, що регламентують правила його діяльності та поведінки.

Принцип гендерної рівності означає забезпечення рівними можливостями, правами і обов'язками жінок та чоловіків під час проходження військової служби. Гендерна ідентичність військовослужбовця не може бути підставою для встановлення обмежень або надання додаткових прав, крім випадків, передбачених Законодавством України.

Слід зазначити, що статути та етичні кодекси є важливими інструментами для запобігання насильству і сексуальним домаганням у секторі безпеки та оборони України. Серед інших положень, в проекті нового уніфікованого Статуту для сектору безпеки та оборони і кодексах етики передбачаються пункти, які розкривають положення щодо забезпечення гендерної рівності та деталізують і регламентують ситуації, які можуть призвести до сексуальних домагань.

Усі військовослужбовці та працівники правоохоронних органів, як і інші громадяни України, є суб'єктами права і зобов'язані дотримуватися його норм. Під час виконання бойових завдань, участі в операціях військовослужбовці також є суб'єктом міжнародного права, включаючи право збройних конфліктів і правила застосування сили. Названі принципи становлять основу стандартів особистої поведінки військовослужбовця як громадянина.

Будь-яка неправомірна поведінка, яка породжує у військовослужбовців та працівників правоохоронних органів відчуття несправедливого ставлення, $\epsilon$ принципово несумісною зі Збройними Силами України та органами правопорядку i не повинна бути терпимою. Дискримінація та домагання можуть також порушувати норми кримінального права: будь-яка форма дискримінації або домагань підриває довіру i впевненість, особливо у керівному складі підрозділу.

Командир (начальник) зобов'язаний попереджати і вчасно виявляти будьякі прояви дискримінації та насильства, у тому числі гендерно-обумовленого, тобто такого, що є наслідком гендерної нерівності у ввіреному йому підрозділі.

$\mathrm{y}$ разі наявності у військовослужбовця чи працівника органів правопорядку інформації про факт гендерно-обумовленого насильства командира у відношенні до підлеглого (підлеглих) він зобов'язаний повідомити про це старшого командира (начальника).

До гендерно зумовленого насильства, окрім іншого, належать сексуальні домагання - дії сексуального характеру, виражені словесно (погрози, залякування, непристойні зауваження) або фізично (доторкання, поплескування), що принижують чи ображають осіб, які перебувають у відносинах підпорядкування [6].

Військовослужбовцям та працівникам органів правопорядку забороняється здійснювати будь-які дії, результатом яких можуть бути фізичні, сексуальні чи психологічні образи або страждання. 
Не бажаними є статеві відносини між військовослужбовцями Збройних Сил України та представниками цивільного населення, які проживають на території виконання бойового завдання, оскільки такі відносини засновані на завчасно нерівному становищі, підривають довіру до Збройних Сил України та ставлять під сумнів професійність військовослужбовців.

За кожним фактом виявлення або повідомлення про наявність гендернообумовленого насильства командир зобов'язаний провести перевірку. У разі встановлення у діях військовослужбовця ознак складу злочину, у тому числі гендерно зумовленого, командир (начальник) зобов'язаний передати матеріали до органів державної влади, уповноважених на проведення розслідування.

У разі встановлення фактів гендерно зумовленого насильства, які не містять ознак складу злочину, командир притягає винну особу до відповідальності у межах наданих повноважень.

Проблематика недискримінації, рівного, відповідального ставлення до громадян, незалежно від статі та інших ознак, мають вивчатися для перетворення з абстрактних термінів на практичні моделі поведінки та ціннісні орієнтири сучасних українських поліцейських і військовослужбовців, всього сектору безпеки в цілому [8].

Повертаючись до тези про те, що Влада - у сучасному розвинутому правовому суспільстві є синонімом слова “відповідальність", зазначимо, що Збройні Сили не є виключенням. Відповідальність є базовим етико-моральним атрибутом військового лідера та фундаментальною демократичною цінністю, що відображена в Кодексі честі цивільного та військового персоналу НАТО. У системі професійної підготовки як в арміях країн-членів НАТО, так і в Україні офіцери i цивільні керівники повинні свідомо, постійно і цілеспрямовано покращувати власні професійні компетентності, карбувати лідерські якості та сприяти розвитку військової організації.

Висновки та перспективи подальших досліджень. В якості висновку слід зазначити, що в сучасному інформаційному суспільстві військовими лідерами можуть бути лише особи, що володіють відповідними професійними компетенціями, розділяють прогресивні демократичні цінності, серед яких не останне місце займає принцип гендерної рівності та здатні брати на себе величезний тягар відповідальності. За умов детального аналізу та впровадження морально-етичних засад, закладених у етичних кодексах поведінки військовослужбовців та цивільного персоналу армій країн-членів НАТО у процес підготовки військовослужбовців сектору безпеки та оборони України, саме такі особистості формуватимуть нову військову еліту, що внесе свій внесок у вирішення сучасних та майбутніх викликів та загроз 3 якими стикається і буде стикатися не лише Україна, а і все людство у XXI столітті.

Дослідження процесу формування гендерної ментальності особового складу військовослужбовців та працівників Збройних Сил України на засадах європейських цінностей $є$ перспективним напрямком наукових досліджень. В перспективі автором планується проведення аналізу особливостей та проблем, 
пов'язаних 3 процесами впровадження принципу гендерної рівності у військовому середовищі.

\section{ЛІТЕРАТУРА}

1. Голик М.М. Кодекс честі офіцера Збройних Сил України як чинник формування корпоративної культури. Збірник наукових праџьь «Гілея: науковий вісник». Дніпро, 2016. №108. С. 91-93.

2. Інформаційне суспільство в світі та Україні: проблеми становлення та закономірності розвитку: колективна монографія / за ред. В. Г. Воронкової. Запоріжжя: ЗДІА, 2017. $282 \mathrm{c.}$

3. Кримець Л. В. Філософія влади та управління науково-освітнім простором: монографія. Київ: Золоті ворота, 2016. 410 с.

4. Крымец Л. В. Социальное взаимодействие в контексте постиндустриального общества на современном этапе развития: монографія. Saarbrucken, Germany: Lap Lambert Academic Publishing, 2012. 163c.

5. Методичний порадник щодо формування ментальності особового складу підрозділу (військової частини) Збройних Сил України на засадах європейських цінностей / під заг. ред. Л. В. Кримець. Київ: НУОУ, 2018. 20 с.

6. Професійна та гендерна ментальність військовослужбовців Збройних Сил України: формування на засадах європейських цінностей : навчальний посібник / під заг. ред. Л. В. Кримець. Київ: НУОУ, 2018. 188 с.

7. Army Leader Development Strategy: http://data.cape.army.mil/web/characterdevelopment-project/repository/alds-2013.pdf (дата звернення 14.05.2019).

8. Krymets L.V. Gender approach and democratic values in the context of the modern generation of military staff's mentality shaping. Гуманітарний вісник Запорізької державної інженерної академії: збірник наукових праць. Запоріжжя, 2018. №74. С. 71-80.

9. NATO Code of Conduct: https://www.nato.int/structur/recruit/info-doc/code-ofconduct.pdf (дата звернення 20.05.2019).

10. Field Manual № 6-22. Leader Development. Headquaters. Departement of the Army. Washington DC, June 2015.

\section{REFERENCES}

1. Holyk, M. (2016). Kodeks chesti ofitsera Zbroinykh Syl Ukrainy yak chynnyk formuvannia korporatyvnoi kultury [Code of honor of an officer of the Armed Forces of Ukraine as a factor in the formation of corporate culture]. Zbirnyk naukovykh prats «Hileia: naukovyi visnyk». 108, 9193.

2. Voronkova,V.G. ed. (2017). Informatsiine suspilstvo v sviti ta Ukraini: problemy stanovlennia ta zakonomirnosti rozvytku: kolektyvna monohrafiia [Information Society in the World and Ukraine: Problems of Formation and Patterns of Development]. Zaporizhzhia: ZDIA, 282.

3. Krymets, L.V. (2016). Filosofiia vlady ta upravlinnia naukovo-osvitnim prostorom: monohrafiia [Philosophy of power and management of scientific and educational space]. Kyiv: Zoloti vorota, 410 .

4. Krymets, L.V. (2012). Sotsyalnoe vzaymodeistvye v kontekste postyndustryalnoho obshchestva na sovremennom эtape razvytyia: monohrafiia [Social interaction in the context of post-industrial society at the present stage of development]. Saarbrucken, Germany: Lap Lambert Academic Publishing, 163.

5. Krymets, L.V. ed. (2018). Metodychnyi poradnyk shchodo formuvannia mentalnosti osobovoho skladu pidrozdilu (viiskovoi chastyny) Zbroinykh Syl Ukrainy na zasadakh yevropeiskykh tsinnostei [Methodical advisor on the formation of the mentality of the personnel of 
the subdivision (military unit) of the Armed Forces of Ukraine on the basis of European values]. Kyiv: NUOU, 20.

6. Krymets, L.V. ed. (2018). Profesiina ta henderna mentalnist viiskovosluzhbovtsiv Zbroinykh Syl Ukrainy: formuvannia na zasadakh yevropeiskykh tsinnostei : navchalnyi posibnyk [Professional and gender mentality of servicemen of the Armed Forces of Ukraine: formation on the basis of European values]. Kyiv: NUOU, 188.

7. Army Leader Development Strategy : http://data.cape.army.mil/web/characterdevelopment-project/repository/alds-2013.pdf .

8. Krymets, L. (2018). Gender approach and democratic values in the context of the modern generation of military staffs mentality shaping. Humanitarnyi visnyk Zaporizkoi derzhavnoi inzhenernoi akademii: zbirnyk naukovykh prats. 74, 71-80. conduct.pdf .

9. NATO Code of Conduct : https://www.nato.int/structur/recruit/info-doc/code-of-

10. Field Manual (2015). Leader Development. Headquaters. Departement of the Army. Washington: DC, 6-22.

\title{
PЕЗЮМЕ
}

Людмила Крымец, доктор философских наук, старший научный сотрудник

Национальный университет обороны Украины имени Ивана Черняховского

Руслан Калениченко, кандидат психологических наук, доцент

\section{Этические кодексы поведения в контексте формирования ментальности военнослужащих и противодействия гендерной дискриминации}

\begin{abstract}
Автором определены аксиологические аспекты современных военных этических кодексов поведения в контексте формирования ментальности военнослужащих сектора безопасности и обороны Украинь в рамках демократических принципов и моральноэтических стандартов, принятых в странах-членах НАТО. В статье проанализировань фундаментальные принщипь и этические категории Кодекса чести офицера Вооруженных Сил Украины, Кодекса поведения военного и гражданского персонала НАTO "The NATO Code of Conduct" и принциипь, заложенные в проекте унифицированного Устава военнослужаших сектора безопасности и обороны Украины с акиентом на концептуализацию принципа гендерного равенства и противодействия гендерной дискриминации.

Ключевые слова: военная этика; военное образование; этический кодекс; кодекс чести военнослужащего; гендерное равенство; гендерная дискриминация; ментальность военнослужащего; демократические иенности.
\end{abstract}

\section{SUMMARY}

Liudmyla Krymets, Doctor of Science in Philosophy, Senior Researcher National Defense University of Ukraine named after Ivan Chernyakhovskyi

Ruslan Kalenichenko,

Candidate of Psychological Science, Aassociate professor

Ethical codes of behavior in the context of forming the mentality of military staff and counteraction of gender discrimination 
Introduction. Ethical Codes, Codes of Honor of Servicemen in the Security and Defense Sector of Ukraine are important issues of forming mentality, upbringing, uniting of the officer corps, development of high moral and psychological preparedness for servicemen to fulfill tasks related to the defense of Ukraine.

Purpose. The purpose of the article is to determine the axiological content of modern military ethical codes of conduct in the context of forming the mentality of the servicemen of the security and defense sector of Ukraine on the basis of democratic principles and moral and ethical standards adopted in NATO member states with a focus on the conceptualization of the principle of gender equality.

Methods. The article analyzes the fundamental principles and ethical categories of the Code of Honor of an officer of the Armed Forces of Ukraine, the NATO Code of Conduct for Military and Civilian Personnel "The NATO Code of Conduct" and the principles enshrined in the draft unified Charter of the security and defense personnel of Ukraine with a focus on the conceptualization of gender equality and countering gender discrimination.

Results. The author identifies the axiological aspects of modern military ethical codes of conduct in the context of the formation of the mentality of the military personnel of the security and defense sector of Ukraine within the framework of democratic principles and moral and ethical standards adopted in NATO member countries.

Any unlawful behavior that generates a sense of unfair treatment of servicemen and law enforcement officers is fundamentally incompatible with the Armed Forces of Ukraine and law enforcement and should not be tolerated. Discrimination and harassment may also violate the rules of criminal law: any form of discrimination or harassment undermines trust and confidence, especially in the leadership of the unit.

Originality Gender-based violence, among other things, includes sexual harassment - acts of a sexual nature, expressed verbally (threats, intimidation, obscene remarks) or physically (touching, squealing), humiliating or offending persons who are in subordination. The commander (chief) is obliged to warn and timely disclose any manifestations of discrimination and violence, including gender-based, that is, the consequence of gender inequality in his entrenched unit.

Conclusion. The Strategic Defense Bulletin of Ukraine provides that the professionalization of the defense forces and the creation of the necessary military reserve in Ukraine should be based on the principles and principles governing the member states of NATO. At the same time, the development of social and humanitarian support for defense forces personnel, primarily servicemen, is associated with changes in the mentality (way of thinking) of the personnel, which, in turn, should be based on European values. Military and law enforcement officers are prohibited from taking any action that may result in physical, sexual or psychological harm or suffering.

Keywords: military ethics; military education; ethical code; military honor code; gender equality; gender discrimination; military mentality; democratic values. 